\title{
A Study on the Implications of GST in Jewellery Business
}

\author{
Reshma Rachel Kuruvilla ${ }^{1}$, P. N. Harikumar ${ }^{2}$ and Liza Alex ${ }^{3}$ \\ ${ }^{1}$ Assistant Professor, Department of Commerce, BCM College, Kottayam, Kerala, India \\ ${ }^{2}$ Associate Professor \& Head, Research and Post-Graduate Department of Commerce \& Tourism Management, \\ Catholicate College, Pathanamthitta, Kerala, India \\ ${ }^{3}$ Assistant Professor, KG College, Pampady, Kerala, India \\ E-Mail: rrk1711@gmail.com
}

\begin{abstract}
GST is a tax reform implemented in the country after long years of debates and discussions. It has affected the citizens and the businesses in manifold ways. For the economy of the country, contributions of the gems and jewellery sector cannot be ignored because exports of gems and jewellery alone contribute around $7 \%$ of the GDP of the country. With the implementation of GST, price of the gems and jewellery might change affecting the business as a whole. Changes happening in the gems and jewellery sector due to implementation of GST on account of Exports, sales on approval basis, exhibition, transfer of old jewellery were discussed by the author.

Keywords: GST, Exports, Job Works, Transfer, Sale, Gems and Jewellery
\end{abstract}

\section{INTRODUCTION}

GST is the single indirect tax system introduced In India, which is imposed on the supply of products and services within the country. Both Central government and the state governments were collectively and separately taking many taxes in various names before the introduction of GST. It has replaced many Indirect Taxes in India. Service Tax, Central Excise Duty, Purchase Tax, Entry Tax, Luxury Tax, Octroi, Local Body Taxes and many similar indirect taxes were subsumed with the introduction of GST into the boundaries of India. This was done with the intention of avoiding cascading effect of taxes.

Model GST law was drafted by a committee formed upon the recommendations of Shri A B Vajpayee, our former Prime minister of India in the year 2000. Representatives from different states across India and centre formed the committee to discuss on the various aspects of the GST draft proposal and based on their study they framed rules on the thresholds, exemptions, taxation of inter-state supplies, and taxation of services. Following this committee, India faced several proposals and amendments in connection with GST. And it was after several years of deadlock in the parliament, that the Goods and Service Tax Act was passed on 29th March 2017. The Act is in effect from 1st July 2017.

Though Government has made GST mandatory, many businesses are still struggling and finding it difficult to tackle the problems that have arisen as a result of the implementation of GST. Unorganized sector is the one which was affected the most due to GST because of the compliance requirements in connection with GST. Small dealers having a turnover below 20 lakhs have to face a further fall in their turnover resulting in a drastic fall in their turnover since, shop owner's switch over their purchases to shops which are compliant with the GST procedures and are hence forced to take GST registration or to close down their businesses. Taking a GST registration mandates GST return filing and compliances since otherwise they will be forced to pay penalty and damages. This will increase the charges for GST. Increased costs due to the hike in taxes may be one of the prime reasons for increased smuggling of gold into the boundaries of India from abroad.

According to the matter published in economic times, currently the organized jewellery segment accounts for $22 \%$ of the jewellery market while $78 \%$ is captured by the local and independent stores. Gems and Jewellery business has huge significance since it makes a contribution of $7 \%$ to the country's GDP. Government has been focusing this as an area for export promotion considering the potential of the sector in generating foreign reserves for the country. As per the information published by India Gold Policy Centre in the article "Viability of a gold exchange in India" (2016), annual volume demand for gold in India is second only behind China indicating a huge potential for future growth. Through the Make in India campaign, Indian Prime minister Shri Modi aims for increasing the overall production in our country. India Brand equity foundation points out India as the largest market for gold jewellery in the world. Gem Jewellery export promotion council asserts that India is one of the largest exporter of Gems and jewellery. And the industry is having an important contribution towards the Indian economy in the form of foreign reserves. Net exports of gems and jewellery from India increased at a compound annual growth rate (CAGR) of 7.01 per cent during the years in between FY05 and FY17.

Gems and jewellery business should be promoted also because of the availability of highly skilled employees and cheap labour in India. India has allowed 100\% FDI through Automatic route for investments to the gems and jewellery market. It was after considering the huge importance for the gems and jewellery sector that this sector was chosen to study about the impact of GST. Through this paper, an attempt was made to analyze the impact of GST on 
Jewellery, i.e. the impact Goods and Services Tax (GST) has created on making charges and on the exchange of gold. Now, Sale of gold jewellery will attract a tax rate of 3\% on the amount sold if supply is a composite one. Customs duty which is outside the ambit of GST will continue to be charged at the rate of $10 \%$ and job works on making charges will be levied at $5 \%$ of the value of job work undertaken. Before the introduction of GST, excise duty was $1 \%$ and $1.5 \%$ VAT (varies with state) along with $10 \%$ customs duty.

Table I Split Up Of Gold Prices Before Gst AND After Gst

\begin{tabular}{|l|c|c|}
\hline \multicolumn{1}{|c|}{ Particulars } & $\begin{array}{c}\text { Price Before } \\
\text { GST }\end{array}$ & $\begin{array}{c}\text { Price after } \\
\text { GST }\end{array}$ \\
\hline Price of Gold (a) & 100 & 100 \\
\hline Customs Duty (10\%) (b) & 10 & 10 \\
\hline c = a+b & 110 & 110 \\
\hline Excise(1\%)(d) & 1.1 & 0 \\
\hline E=c+d & 111.1 & 110 \\
\hline VAT(1.2\%)(F) & 1.3 & 0 \\
\hline G =E+F & 112.4 & 110 \\
\hline GST (3\%) (H) & 0 & 3.3 \\
\hline I=H+G & 112.4 & 113.3 \\
\hline $\begin{array}{l}\text { Making charges(12\% of } \\
\text { c)(j) }\end{array}$ & 13.2 & 13.2 \\
\hline K= i+j & 125.6 & 126.5 \\
\hline $\begin{array}{l}\text { GST on making charges } \\
\text { (5\%) (L) }\end{array}$ & 0 & 0.7 \\
\hline $\begin{array}{l}\text { Total price of jewellery } \\
\text { (M=K+L) }\end{array}$ & 125.6 & 127.2 \\
\hline Total taxes due & 12 & 14 \\
\hline
\end{tabular}

Under GST, taxable event is the supply of goods or services. And supply has been defined in the act under section 2(92) read with section 3 as follows, 'Supply' includes all forms of supply of goods and/or services such as sale, barter, transfer, exchange, licence, rental, lease or disposal in whatever name being called is made or agreed to be made for a consideration by a person in the course or furtherance of business.

Importance of supply in GST is that it will replace multiple taxable events such as manufacturing, service and sales which were subjected to tax during the existence of previous legislations of indirect taxes. Apart from the definition, Schedules I to III are added along with the definition of supply to give clarity for the provisions related to supply. In the case of gold jewellery, GST is imposed on making charges and in the sale value of gold. Therefore GST is being charged on the goods supplied as well as in the services provided.

\section{PURCHASE/SALE OF JEWELLERY}

When a person purchases jewellery from a registered business owner and the businessman has charged making charges and rate of gold jointly in the invoice, then it would be treated as a composite supply and GST at the rate of 3\% alone would be charged from the consumer., But if the invoice mentions making charge and the rate of gold separately, then GST at the rate of $3 \%$ on Gold purchase and $18 \%$ on making charge has to be collected from the customer.

\section{TRANSFER OF USED GOLD JEWELLERY TO A JEWELLER}

If an individual customer sells his old jewellery to a registered jewellery business owner, then that need not be considered as a supply since such a transfer is not done as a regular business transaction but is being undertaken seldom. If old jewellery is exchanged for the new jewellery, transaction value of the exchange would be on the basis of goods having similar character and nature to that of the goods being exchanged for the old product and GST would be charged on the transaction value computed based on the like goods.

Purchase from an individual customer by the jeweler will not attract reverse charge mechanism too on such purchases. But if the supply is from an unregistered supplier to a registered supplier, then reverse charge will come into play.

\section{Jewellery Sent for Exhibition}

When goods are being sent out to a person other than a customer, It is not treated as a sale due to lack of a consideration ,but simply a transfer which may be returned back if sale doesn't complete during the exhibition. A delivery challan will be enough in the case of such a transaction.

\section{Job Works Related to Jewellerey}

Job work has been explained in the act as 'any treatment or process undertaken by a person on goods belonging to another registered person. This explanation implies that making or repairing works undertaken by the jobworker upon the request of the customer directly has to be treated separately apart from the job works undertaken from registered business units.

Making or repairing works upon the request of customers directly would attract GST at the rate of $18 \%$ whereas job works from a registered person would attract $5 \%$ only. Supplying of goods for job work would attract GST at the rate of $3 \%$. Purchase of goods from individual customers has to be treated as unregistered purchases.

\section{E. Jewels Sold on Approval Basis}

If goods are sold on the condition of return by approval, then GST need not be paid if goods are returned back within the period of six months from the date of removal of goods. Delivery in this case will be made through a delivery challan instead of a tax invoice as per GST rules and 
liability to pay GST will accrue upon the completion of six months from the date of removal.

\section{F. Exports of Jewellery}

Exports of jewellery also are zero rated like other exports, and input tax credit on purchases can be claimed as duty drawback. Procedures for claiming the duty drawback has been simplified with the introduction of GST. There are two options for an exporter to claim the refund of tax paid on purchases. (1) the An exporter can exempt himself from the payment of IGST if he is supplying goods or services, based on letter of undertaking or on the basis of a bond after following all the conditions connected with the bond or LUT. (2) A shipping bill filed for the purpose of export is considered as an application for refund of input tax credit. But for both the options, export manifest has to be compulsorily filed by the person supposed to do it. Nearly $13 \%$ of India's overall merchandise exports is contributed by gems and jewellery sector alone. There has been a drastic fall in the Exports of gold in the Q1 of 2018. According to the material published by the Gems and Jewellery Export Promotion Council (GJEPC), net export from gems and jewellery has declined 7.4 per cent to $\$ 16.8$ billion in April-September, the first six months of this financial year, from $\$ 18.2$ bn during the previous year.

\section{CONCLUSION}

With GST in place, the gems and jewellery sector in India would be able to have competitive prices while promoting the organized sector more and discarding the units which are not tax compliant in the long run. Simplified process of claiming input tax credit and the provision of input tax credit even on service has made the entire process transparent and error free. Interactions with the dealers gave me an understanding that In spite of all the positives, there remains certain confusions on GST procedures which has to resolve at the earliest to support the gems and jewellery sector.

\section{REFERENCES}

[1] Dani, S. (2016). A Research Paper on an Impact of Goods and Service Tax (GST) on Indian Economy. Business and Economics Journal, 07(04). https://doi.org/10.4172/2151-6219.1000264

[2] Garg, Y., \& Gupta, J. (n.d.). an Exploratory Study on Evolution \& Implementation of Gst in India, 240-244.

[3] GST Impact on Gold: Impact of GST on gold and gold jewellery prices - Times of India. (n.d.). Retrieved November 22, 2018, from https://timesofindia.indiatimes.com/business/faqs/gold-faqs/impactof-gst-on-gold-and-gold-jewellery-prices/articleshow/60827287.cms

[4] GST rates: GST impact on gold jewellery: Larger players to emerge as biggest beneficiaries. (n.d.). Retrieved November 22, 2018, from https:/economictimes.indiatimes.com/industry/cons-roducts/fashion/-cosmetics-/-jewellery/gst-impact-on-gold-jewellery-larger-playersto-emerge-as-biggest-beneficiaries/articleshow/59376739.cms

[5] Impact of GST on Gold and Gold Jewellery Prices. (n.d.). Retrieved November 22, 2018, from https://cleartax.in/s/gst-impact-on-gold

[6] Leemput, E. Van, Wiencek, E. A., Leemput, E. Van, \& Wiencek, E. A. (2017). Board of Governors of the Federal Reserve System The Effect of the GST on Indian Growth, (March).

[7] Shailesh, A., \& Pradesh, U. (2016). A study on impact of goods and services tax on Indian economy : A key tax reform, 2(10), 76-80. 